\title{
Administrasi Dan Tanggung Jawab Pejabat Pembuat Akta Tanah Terhadap Pembatalan Akta Yang Dibuatnya
}

\author{
Meralda Amala Istighfarin \\ Magister Kenotariatan Fakultas Hukum Universitas Islam Indonesia Yogyakarta Indonesia \\ Jln. Cik Di Tiro No. 1 Yogyakarta Indonesia \\ meraldamala@gmail.com
}

\begin{tabular}{ll}
\hline Key Word: & Abstract \\
Administration, & Problems in society are growing over time. The author takes research material on \\
Deed Cancellation, "Administration and Responsibilities of Land Deed Making Officials (PPAT) for \\
PPAT Protocol, Cancellation of Deeds Made". This research is an empirical legal research supported \\
Responsibility & by normative data. Research data were collected through interviews, literature \\
& studies, document studies. The analysis was carried out using qualitative data \\
analysis methods. The results of this study conclude that the completion of the & administrative protocol and PPAT's responsibility for the canceled deed is carried \\
out before registration with the Land Office is responsible for completing the \\
administrative protocol at his office, namely by attaching a copy of the cancellation \\
of the notarial deed for the cancellation of the deed, or completing the administrative \\
protocol at his office, namely by attaching a copy of the court judge's decision on the \\
cancellation of the deed
\end{tabular}

\begin{tabular}{ll}
\hline Kata-kata Kunci: & Abstrak \\
\cline { 2 - 3 } Administrasi, & Problematika dalam masyarakat semakin berkembang seiring berjalannya \\
Protokol PPAT, & waktu. Penulis mengambil bahan penelitian mengenai "Administrasi dan \\
Pembatalan Akta, & Tanggungjawab Pejabat Pembuat Akta Tanah (PPAT) terhadap Pembatalan \\
Tanggung Jawab & Akta yang Dibuatnya". Penelitian ini merupakan penelitian hukum empiris \\
& dengan ditunjang data normatif. Data penelitian dikumpulkan melalui \\
& wawancara, studi pustaka, studi dokumen. Analisis dilakukan dengan \\
& menggunakan metode analisis data kualitatif. Hasil penelitian ini \\
& menyimpulkan penyelesaian protokol administrasi dan tanggung jawab \\
& PPAT atas aktanya yang dibatalkan dilakukan sebelum dilakukan \\
& pendaftaran ke Kantor Pertanahan bertanggungjawab melakukan \\
& penyelesaian protokol administrasi pada kantornya, yakni dengan \\
& melampirkan salinan pembatalan akta notariil atas pembatalan aktanya, \\
& ataupun melakukan penyelesaian protokol administrasi pada kantornya, \\
& yakni dengan melampirkan salinan putusan hakim pengadilan atas \\
& pembatalan aktanya
\end{tabular}

\section{Pendahuluan}

Definisi PPAT ialah seseorang yang diangkat dan diberi kekuasaan oleh undangundang untuk membuat akta, di mana di dalam akta yang dibuatnya itu memuat klausula atau aturan yang mengatur hubungan hukum antara para pihak, yang berkaitan dengan hak atas tanah dan/atau hak milik atas satuan rumah susun. ${ }^{1}$ Aturan dalam Pasal 24 PP No. 37 Tahun 1998 mengenai Peraturan Jabatan untuk Pejabat Pembuat $\underline{\text { Akta }}$ Tanah (PP No. 37 Tahun 1998) memberikan aturan bahwa "Ketentuan-ketentuan lebih

\footnotetext{
${ }^{1}$ Salim HS., Teknik Pembuatan Akta Pejabat Pembuat Akta Tanah, Raja Grafindo Persada, Jakarta, 2016, hlm. 90
} 
lanjut berkaitan dengan tata cara pembuatan akta PPAT diatur dalam dengan jelas dalam peraturan perundang-undangan mengenai pendaftaran tanah".

Pendaftaran tanah sangat penting untuk menjamin kepastian hukum bukan hanya untuk memastikan siapa pemilik tanah pada saat ini, akan tetapi termasuk pula perlindungan hukum bagi mereka yang akan memperoleh hak atas bidang tanah tersebut pada waktu yang akan datang. Menurut Pasal 3, Peraturan Pemerintah Nomor 24 Tahun 1997 tentang Pendaftaran Tanah, tujuan diadakan pendaftaran tanah adalah:

1. Untuk memberikan kepastian hukum dan perlindungan hukum kepada pemegang hak atas suatu bidang tanah, satuan rumah susun dan hak-hak lain yang terdaftar agar dengan mudah dapat membuktikan dirinya sebagai pemegang hak yang bersangkutan;

2. Untuk menyediakan informasi kepada pihak-pihak yang berkepentingan termasuk pemerintah agar dengan mudah dapat memperoleh data yang diperlukan dalam mengadakan perbuatan hukum mengenai bidang- bidang tanah dan satuan-satuan rumah susun yang sudah terdaftar;

3. Untuk tertib administrasi pertanahan.

Guna menciptakan ketertiban di bidang pertanahan khususnya yang menyangkut pejabat yang berwenang membuat akta jual beli yang menyangkut tanah, pemerintah dibantu oleh Pejabat Pembuat Akta Tanah (PPAT) merupakan pejabat yang berwenang menurut ketentuan dalam Undang-Undang Pokok Agraria Nomor 5 Tahun 1960 dan Peraturan Pemerintah Nomor: 10 Tahun 1961 juncto Peraturan Pemerintah Nomor 24 Tahun 1997 juncto Peraturan Pemerintah Nomor 37 Tahun 1998.

Dalam rangka kelancaran pelaksanaan tugas pendaftaran hak atas tanah, pemerintah memberikan kewenangan kepada pejabat lain untuk membantu BPN. Keberadaan pejabat dalam tatanan ketatanegaraan sangat dibutuhkan karena pejabat tersebut merupakan pelaksana tugas-tugas personifikasi negara. ${ }^{2}$ Dapat dikatakan bahwa PPAT merupakan perpanjangan tangan dari BPN, yang khusus mengenai pembuatan akta-akta hak atas tanah yang merupakan syarat formil dalam pendaftaran di Kantor Pertanahan.

Tugas dan kewenangan pejabat umum yaitu memberikan pelayanan kepada umum. Konsep umum pada definisi ini bukan pada semua bidang, tetapi hanya pada bidang-bidang tertentu dan khusus, seperti pembuatan akta. ${ }^{3}$ Oleh karena itu, PPAT berwenang membuat akta dari pada perjanjian-perjanjian yang bermaksud memindahkan hak atas tanah, memberikan sesuatu hak baru atas tanah atau meminjam uang dengan hak atas tanah sebagai tanggungan. ${ }^{4}$

Untuk melaksanakan tugas pokok tersebut maka oleh Pasal 3 PP Nomor 37 Tahun 1998, PPAT diberi kewenangan untuk memformulasikan perbuatan hukum tersebut ke dalam Akta PPAT sebagai bukti telah dilaksanakannya perbuatan hukum tertentu mengenai hak atas tanah atau Hak Milik Atas Satuan Rumah Susun. Dikaji dari sudut pandang kewenangan, PPAT mempunyai kewenangan yaitu yang berkaitan dengan:

1. Pemindahan hak atas tanah;

2 Widhi Handoko, Kebijakan Hukum Pertanahan “Sebuah Refleksi Keadilan Hukum Progresif”, Ctk. Pertama, Thafa Media, Yogyakarta, 2014, hlm. 161

${ }^{3}$ Salim HS, Op. Cit., hlm. 88

${ }^{4}$ Samun Ismaya, Hukum Administrasi Pertanahan, Graha Ilmu, Yogyakarta, 2013, hlm. 177 
2. Pemindahan hak milik atas satuan rumah susun;

3. Pembebasan hak atas tanah; dan

4. Surat kuasa membebankan hak tanggungan.

Selain adanya tugas dan kewenangan dalam PPAT juga adanya kewajiban yang perlu diketahui, yakni salah satunya kewajiban terhadap protokol itu sendiri. Protokol PPAT adalah kumpulan dokumen yang harus disimpan dan dipelihara oleh PPAT yang terdiri warkah pendukung akta, arsip laporan, agenda dan surat-surat lainnya.

Namun tentunya dalam pembuatan akta pastilah terdapat kendala-kendala. Hal ini karena secara kodrati, PPAT sebagai manusia dapat melakukan kesalahan-kesalahan baik yang bersifat pribadi maupun yang menyangkut profesionalitas dalam menjalankan tugas jabatannya. Seorang PPAT tidak semuanya sesuai dalam menjalankan jabatannya dan tidak sedikit mengalami permasalahan terkait aktanya, salah satunya mengenai pembatalan akta PPAT tersebut. Pembatalan akta PPAT dapat disebabkan banyak hal, termasuk dibatalkan berdasarkan putusan pengadilan karena terjadi permasalahan antar para pihak atau dibatalkan oleh para pihak melalui putusan pengadilan.

Seorang PPAT dalam menjalankan tugas dan kewenangan jabatannya tersebut, khususnya berkaitan dengan prosedur pembuatan akta PPAT adakalanya melakukan kesalahan, dan kesalahan tersebut bisa saja menyangkut persyaratan formil maupun materil, misalnya: kesalahan mengenai ketidakwenangan PPAT dalam membuat akta otentik, yang berakibat hilangnya otensitas akta yang dibuatnya, atau kekuatan pembuktian akta tersebut tidak lagi sebagai alat bukti yang lengkap atau sempurna, di antara dan bagi pihak-pihak yang berkepentingan, melainkan menjadi akta atau surat di bawah tangan, dimana kesalahan tersebut bisa saja dilakukan dengan sengaja maupun tidak disengaja. ${ }^{5}$

Terdapat permasalahan yang terjadi, bahwa PPAT dalam pembuatan akta harus sesuai prosedur khususnya pada Peraturan Pemerintah Nomor 37 Tahun 1998 yang diubah menjadi Peraturan Pemerintah Nomor 24 Tahun 2016 tentang Peraturan Jabatan Pembuat Pejabat Akta Tanah, selain prosedur pembuatan akta PPAT, seorang PPAT harus sesuai dalam melakukan pemberkasan administrasi terutama dalam buku daftar akta harus urut tanpa ada coretan, gantian dan lompatan nomor pada akta yang telah dibuat. Akta PPAT dapat dibatalkan sebelum dilakukan pendaftaran ke Kantor Pertanahan, jika dibatalkan aktanya bagaimana protokol termasuk warkah yang telah terisi pada administrasi PPAT, dan jika batal setelah dilakukan pendaftaran di Kantor Pertanahan, bagaimana penyelesaiannya pada Kantor Pertanahan dan administrasinya pada protokol PPAT. Hal ini apakah mengakibatkan kekosongan pada nomor dan tanggal akta buku daftar akta yang telah ditulis oleh PPAT, kemudian apakah menjadi masalah jika ada pemeriksaan oleh Kantor Pertanahan setempat yang tidak sesuai isi administrasi dengan akta yang dibatalkan. Maka dari itulah perlu dikaji lebih lanjut mengenai "ADMINISTRASI DAN TANGGUNG JAWAB PEJABAT PEMBUAT AKTA TANAH (PPAT) TERHADAP PEMBATALAN AKTA YANG DIBUATNYA"

${ }^{5}$ Dhea Tri Febriana \& Ahars Sulaiman, “Tanggung Jawab Pejabat Pembuat Akta Tanah (PPAT) Dalam Pembuatan Akta Jual Beli Tanah Berdasarkan Peraturan Pemerintah Republik Indonesia Nomor 24 Tahun 2016 Tentang PPAT”, Jurnal Petita, Vol. 1, No. 1, Juni 2019, hlm. 131 


\section{Rumusan Masalah}

Rumusan masalah dalam penelitian ini adalah, pertama, bagaimana penyelesaian protokol administrasi dan tanggung jawab PPAT atas akta PPAT yang dibatalkan sebelum dilakukan pendaftaran ke Kantor Pertanahan? Kedua, bagaimana penyelesaian protokol administrasi dan tanggung jawab PPAT atas akta PPAT yang dibatalkan setelah dilakukan pendaftaran ke Kantor Pertanahan?

\section{Tujuan Penelitian}

Penelitian ini bertujuan untuk mengetahui dan menganilisis, pertama, penyelesaian protokol administrasi dan tangggung jawab PPAT atas akta PPAT yang dibatalkan sebelum dilakukan pendaftaran ke Kantor Pertanahan; Kedua, penyelesaian protokol administrasi dan tangggung jawab PPAT atas akta PPAT yang dibatalkan setelah dilakukan pendaftaran ke Kantor Pertanahan.

\section{Metode Penelitian}

Penelitian ini bersifat empiris-normatif dengan pendekatan kasus dan perundangundangan dan dianalisa menggunakan metode kualitatif. Data diperoleh dari wawancara dan studi pustaka.

\section{Hasil Penelitian dan Pembahasan}

Penyelesaian Protokol Administrasi dan Tanggung Jawab PPAT atas Akta PPAT yang Dibatalkan Sebelum Dilakukan Pendaftaran ke Kantor Pertanahan

Dalam hal ini, walaupun PPAT merupakan pejabat umum yang dapat membuat berbagai macam akta, namun PPAT tidak dapat membatalkan akta yang dibuatnya sendiri. PPAT mempunyai kewenangan yang berkaitan dengan:

1. Pemindahan hak atas tanah;

2. Pemindahan hak milik atas satuan rumah susun;

3. Pembebanan hak atas tanah; dan

4. Surat kuasa membebankan hak tanggungan. ${ }^{6}$

Berdasarkan ketentuan-ketentuan sebagaimana telah diuraikan, PPAT hanya memiliki kewenangan untuk membuat 8 macam akta yang menerangkan atau membuktikan telah dilakukannya delapan macam perbuatan hukum. Perbuatan hukum tertentu sebagaimana disebutkan di dalam ketentuan Pasal 2 ayat (1) PP Nomor 37 Tahun 1998, adalah sebagaimana diatur di dalam ketentuan Pasal 2 ayat (2) PP Nomor 37 Tahun 1998, yaitu:

1. Jual Beli

2. Tukar Menukar

3. Hibah

4. Pemasukan Ke Dalam Perusahaan (Inbreng)

5. Pembagian Hak Bersama

6. Pemberian Hak Guna Bangunan/Hak Pakai atas tanah Hak Milik 
7. Pemberian Hak Tanggungan

8. Pemberian Kuasa Membebankan Hak Tanggungan

Perbuatan hukum di luar atau selain apa yang dinyatakan pada Pasal 2 ayat (2) PP No. 37 Tahun 1998, meskipun berkaitan dengan hak atas tanah atau hak milik atas satuan rumah susun, bukan menjadi kewenangan PPAT untuk membuatkan aktanya, seperti misalnya perbuatan hukum turun waris yang mana objek warisan adalah hak milik atas tanah, atau perbuatan hukum pelepasan hak atas tanah, ataupun pembatalan terhadap pemberian hak atas tanah.

Jika dilakukan pembatalan sebelum dilakukan pendaftaran ke kantor pertanahan, dapat dilakukan dengan akta yang dibuat di hadapan Notaris karena akta perbuatan yang tersebut dalam akta PPAT adalah perbuatan perdata para pihak atau akta partij. Akta partij dapat didefinisikan sebagai akta yang dibuat di hadapan Notaris, suatu akta yang dibuat berdasarkan keterangan atau perbuatan pihak yang menghadap Notaris, dan keterangan atau perbuatan itu agar dikonstatir oleh Notaris untuk dibuatkan akta, seperti untuk tindakan hukum sepihak dan perjanjian dibuat dalam bentuk akta pihak (partij). ${ }^{7}$

Notaris dalam membuat akta partij hanya sebagai pihak penengah dan membuat akta berdasarkan keinginan dari kedua belah pihak. Pejabat notaris fungsinya hanya mencatatkan (menuliskan) apa yang dikehendaki oleh para pihak yang menghadap Notaris tanpa ada kewajiban baginya untuk menyelidiki secara materiil hal-hal yang dikemukakan oleh penghadap kepadanya. Akta yang dihasilkan Notaris sebagai pejabat umum merupakan akta autentik yang berbeda dengan akta yang dibuat oleh para pihak yang berkepentingan tanpa disertai keberadaan Notaris. ${ }^{8}$

PPAT yang dalam hal ini tidak menjabat sebagai Notaris, dapat meminta akta pembatalan kepada seorang yang memang sebagai Notaris untuk dibuatkan akta pembatalan notariil guna membatalkan akta yang dibuat oleh PPAT tersebut. Pembatalan ini dilakukan oleh para pihak, dengan pengajuan salah satu pihak untuk memohonkan pembatalan kemudian melalui kesepakatan untuk dibatalkannya akta PPAT yang berupa akta pembatalan notariil yang dibuat dihadapan notaris. Kemudian setelah dilakukan akta pembatalan yang berupa minuta, PPAT berhak menerima salinan atas akta pembatalan notariil tersebut, serta notaris wajib menyimpan minuta dan menyimpannya sebagai bagian dari protokol notaris.

Istilah pembatalan akta PPAT dalam hal ini bersifat aktif, artinya meskipun syaratsyarat perjanjian telah terpenuhi, tapi para pihak yang terlibat dalam perjanjian tersebut berkehendak agar perjanjian yang dibuat tidak mengikat dirinya lagi dengan alasan tertentu, baik atas dasar kesepakatan atau dengan mengajukan gugatan pembatalan ke pengadilan umum, misalnya para pihak telah sepakat untuk membatalkan akta yang pernah dibuatnya, atau diketahui ada aspek formal akta yang tidak dipenuhi, yang tidak diketahui sebelumnya, dan para pihak ingin membatalkannya.

7 https://www.hukumonline.com/klinik/detail/ulasan/cl1996/perbedaan-akta-yang-dibuat-oleh-notarisdengan-akta-yang-dibuat-di-hadapan-notaris/, diakses pada 13/10/2021 pukul 15.38 WIB

${ }^{8}$ Rio Utomo Hably \& Gunawan Djajaputra, "Kewenangan Notaris Dalam Hal Membuat Akta Partij (Contoh Kasus Putusan Mahkamah Agung Nomor: 1003 K/PID/2015)", Jurnal Hukum Adigama, Volume 2 Nomor 2, Desember 2019, hlm. 2 
Dari hasil penelitian penulis pada salah satu PPAT di Kota Yogyakarta, yang pernah melakukan pembatalan akta PPAT dengan akta pembatalan notariil. Pembatalan akta terjadi ketika sebelum didaftarkan pada Kantor Pertanahan Kota Yogyakarta. PPAT tersebut melakukan pembatalan dengan akta notariil, yang mana PPAT tersebut juga menjabat sebagai Notaris. Akibat hukum dari pembatalan suatu akta tersebut yaitu dari semula dianggap tidak pernah ada dilahirkan suatu perjanjian dan tidak pernah ada suatu perikatan. ${ }^{9}$

Dalam protokol PPAT yakni seperti minuta dan warkahnya dapat dibuatkan salinan dan akta pembatalan notariil atas pembatalan akta PPAT, serta dalam buku daftar akta dan laporan bulanan yang tidak boleh ada pengurangan ataupun pencoretan, hanya perlu dituliskan adanya pembatalan atas akta PPAT tersebut. Walaupun dianggap tidak pernah ada, terhadap administrasi yakni berupa nomor dan tanggal yang telah tercatat pada administrasi (buku daftar akta maupun laporan bulanan) ternyata tetap ada, namun perlu dilampirkan Akta Pembatalan Notariil tersebut. Adanya Akta Pembatalan Notariil juga dapat dijadikan sebagai dasar jika dilakukan pemeriksaan pada Akta PPAT yang telah dibatalkan tersebut, dan juga dapat dijadikan dasar untuk melakukan pengajuan restitusi.

Seorang PPAT dituntut untuk memberikan pelayanan yang terbaik kepada masyarakat, maka sudah seperti menjadi suatu kewajiban bagi seorang PPAT untuk membantu masyarakat mengurus beberapa hal dengan maksimal. Sama halnya ketika para pihak yang bersangkutan dalam akta PPAT telah setuju melakukan pembatalan, maka PPAT mempunyai kewajiban untuk membantu melakukan pembatalan akta yang telah dibuatnya hingga proses pembatalan selesai. Walaupun PPAT yang bersangkutan tidak menjabat sebagai Notaris, namun PPAT berkewajiban untuk melakukan pembatalan aktanya di hadapan Notaris.

PPAT juga bertanggungjawab melakukan penyelesaian protokol administrasi pada kantornya, yakni dengan melampirkan salinan pembatalan akta notariil atas pembatalan aktanya, jika dilakukan pemeriksaan maka PPAT dapat menunjukkan salinan akta pembatalan tersebut.

Pemeriksaan yang dilakukan pada PPAT memuat protokol administrasi PPAT perbulannya, sehingga jika ada pembatalan yang telah dilakukan pada bulan yang berbeda dengan aktanya, maka PPAT dapat melampirkannya secara terpisah sebagai laporan atas pemeriksaan protokol PPAT.

Penulis berpendapat jika PPAT ketika para pihak dalam aktanya sudah bersepakat dan meminta pembatalan atas akta PPAT tersebut, namun PPAT tidak melakukan tanggung jawabnya untuk dilakukan pembatalan serta tidak melampirkan salinan pada masing-masing protokol dengan akta pembatalan tersebut, maka PPAT dapat dikenakan sanksi secara administratif.

\section{Penyelesaian Protokol Administrasi dan Tanggung Jawab PPAT atas Akta PPAT yang Dibatalkan sebelum Dilakukan Pendaftaran ke Kantor Pertanahan}

Mengenai pembatalan akta PPAT, pembatalan tersebut dalam proses pendaftaran di Kantor Pertanahan, dimana menurut Pasal 45 PP No. 24 Tahun 1997 mewajibkan harus

\footnotetext{
${ }^{9}$ Wawancara dengan PPAT Kota Yogyakarta, pada 29/06/2021, pukul 11.15 WIB
} 
dengan putusan pengadilan karena pembatalannya perlu mendapat pengkajian yang cermat. Bahwa akta perbuatan hukum yang kemudian dalam akta PPAT adalah perbuatan para pihak. Jika para pihak sepakat atau tidak ada berkeberatan, para pihak datang kepada notaris untuk membuat akta pembatalan. Akan tetapi, jika para pihak bersengketa, salah satu pihak dapat mengajukan pembatalan ke pengadilan umum atau pengadilan negeri. Ketika diajukan pembatalan, kantor pertanahan berwenang untuk mengeluarkan surat keputusan pembatalan pendaftaran tersebut..$^{10}$

Dari hasil penelitian penulis pada Kantor Pertanahan Kota Yogyakarta, biasanya pembatalan akta PPAT yang sering dilakukan pada Kantor Pertanahan Kota Yogyakarta adalah pembatalan menggunakan dasar adanya putusan hakim, karena adanya sengketa para pihak terhadap akta tersebut. Sedangkan pembatalan akta PPAT yang dilakukan sebelum dilakukannya pendaftaran ke kantor pertanahan dengan akta pembatalan notariil belum pernah ada dan dilakukan pada Kantor Pertanahan Kota Yogyakarta.

Pembatalan akta PPAT ketika belum terjadi peralihan hak, administrasinya belum sepenuhnya tercatat pada Kantor Pertanahan Kota Yogyakarta, ketika sudah terjadi peralihan hak atau selesai proses pendaftaran biasanya di Kantor Pertanahan Kota Yogyakarta pembatalan yang dilakukan terhadap akta PPAT menggunakan dasar putusan hakim pada pengadilan yang bersangkutan.11

Pembatalan terhadap akta PPAT yakni para pihak yang bersangkutan atau pihak yang memenangkan sengketa dalam putusan pengadilan yang harus sudah berkekuatan hukum tetap (incracht) dan tidak ada upaya hukum lagi. Pihak yang bersangkutan mengurus ke Kantor Pertanahan untuk memintakan sesuai dengan bunyi yang ada dalam putusan, apakah membatalkan peralihan atau membatalkan hak atas tanah tersebut, kemudian membayar penerimaan negara bukan pajak (PNBP) sebesar Rp. $50.000,00$ dan bea perolehan hak atas tanah dan bangunan (BPHTB)

Administrasi PPAT harus mengikuti aturan sesuai Kantor Pertanahan contohnya seperti prosedur pembatalan akta PPAT dan prosedur administrasi setelah ada pembatalan tersebut. Ketika ada pembatalan tidak disampaikan kepada Kantor Pertanahan, kedepannya dapat terjadi sengketa kemudian timbul perkara dan dilakukan blokir tanah tersebut oleh Kantor Pertanahan.

Setelah adanya pembatalan, maka Kantor Pertanahan menuliskan bahwa peralihan berdasarkan putusan pengadilan nomor perkara yang telah inkracht. Secara formil di Kantor Pertanahan tidak tercantum akta nomor sekian dibatalkan, namun pada akta tersebut dilampirkan putusan pengadilan. Sehingga di Kantor Pertanahan melakukan peralihan karena pembatalan yang berdasarkan putusan pengadilan. Kemudian pihak memohonkan pembatalan akta PPAT dan selesai mengikuti mekanismenya, sehingga Kantor Pertanahan Kota Yogyakarta mengeluarkan Berita Acara Pencabutan sebagai bentuk tindak lanjut atas pembatalan akta tersebut.

Penyelesaian administrasinya pada kantor PPAT jika dilakukan pembatalan akta PPAT setelah didaftarkan, yaitu akta PPAT yang dibatalkan tersebut dilampirkan

${ }^{10}$ Habib Adjie, Merajut Pemikiran dalam Dunia Notaris dan PPAT, cet. 2, PT Citra Aditya Bakti, Bandung, 2014, hlm. 96

11 Wawancara dengan Kepala Seksi Pemberian Hak, Kantor Pertanahan Kota Yogyakarta, pada 22/07/2021, pukul $11.20 \mathrm{WIB}$ 
putusan pengadilan. Dalam protokol PPAT yakni seperti minuta dan warkahnya dapat dilampirkan putusan hakim pengadilan atas pembatalan akta PPAT, serta dalam buku daftar akta terhadap akta PPAT yang telah dibatalkan hanya perlu dituliskan adanya pembatalan, karena perlu diingat dalam buku daftar akta tidak boleh ada pengurangan ataupun pencoretan. ${ }^{12}$

Para pihak yang bersengketa kemudian melakukan pembatalan setelah didaftarkan di Kantor Pertanahan menggunakan dasar putusan hakim pengadilan. Walaupun PPAT yang bersangkutan hanya sebagai saksi atas sengketa tersebut, dan setelah ada pembatalan yang berkewajiban mengurus pada Kantor Pertanahan ialah pihak yang menang atau diuntungkan atas pembatalan tersebut, namun PPAT berkewajiban secara moril untuk membantu melakukan pembatalan aktanya yang sudah didaftarkan tersebut di Kantor Pertanahan dengan mengikuti mekanisme dan prosedur yang telah ditetapkan oleh Kantor Pertanahan yang bersangkutan.

PPAT juga bertanggungjawab melakukan penyelesaian protokol administrasi pada kantornya, yakni dengan melampirkan salinan putusan pengadilan atas dibatalkannya akta PPAT pada setiap protokol PPAT, jika dilakukan pemeriksaan maka PPAT dapat menunjukkan salinan putusan pengadilan atas dibatalkannya akta PPAT tersebut.

Tanggung jawab karena kesalahan dan kelalaian yang dilakukan PPAT dapat terminimalisir dengan adanya Pengawasan yang sangat ketat oleh Menteri. Seperti dalam Permen Nomor 2 Tahun 2018 pengawasan yang diatur mencakup tentang penegakan aturan hukum yang sesuai dengan ketentuan peraturan perundangundangan. Penegakan hukum tersebut dilakukan atas temuan dari Kementerian terhadap pelanggaran dalam pelaksanaan jabatan atau terdapat pengaduan dari peroangan atau badan hukum. Penegakan hukum atas pelanggaran yang dilakukan oleh PPAT di atas dapat berupa terguran tertulis, pemberhentian sementara, pemberhentian dengan hormat, atau dengan pemberhentian tidak hormat.

\section{Penutup}

Penyelesaian protokol administrasi PPAT dan tanggung jawab terhadap pembatalan akta PPAT yang dilakukan sebelum ataupun setelah dilakukan pendaftaran ke Kantor Pertanahan yaitu dengan menggunakan akta yang dibuat dihadapan Notaris secara notariil ataupun dengan menggunakan dasar putusan hakim pengadilan, sehingga jika dilakukan pemeriksaan oleh pihak kantor pertanahan, akta pembatalan notariil ataupun putusan hakim pengadilan sebagai bukti telah dilakukannya pembatalan terhadap akta PPAT tersebut. PPAT bertanggungjawab melakukan penyelesaian protokol administrasi pada kantornya, yakni dengan melampirkan salinan pembatalan akta notariil ataupun putusan hakim pengadilan, jika dilakukan pemeriksaan maka PPAT dapat menunjukkan lampiran tersebut.

Diharapkan PPAT dalam melakukan pembuatan akta hendaknya berpijak pada ketentuan Peraturan Perundang-Undangan terkait ke PPAT-an yang ada, karena akta otentik yang dibuat akan mempengaruhi kepastian hukum peralihan hak atas tanah

12 Wawancara dengan PPAT Kota Yogyakarta, pada 29/06/2021, pukul 11.27 WIB 
sehingga dapat mengurangi timbulnya permasalahan dan konflik pertanahan, baik secara yuridis maupun teknis dan administratif. PPAT seyogyanya lebih memperhatikan dan memahami ketentuan-ketentuan yang terkait dengan pelaksanaan tugas jabatannya agar terhindar dari sanksi pemberhentian dan denda administratif.

\section{Daftar Pustaka}

\section{Buku}

Adjie, Habib, Merajut Pemikiran dalam Dunia Notaris dan PPAT, PT Citra Aditya Bakti, Bandung, 2014

Handoko, Windhi, Kebijakan Hukum Pertanahan "Sebuah Refleksi Keadilan Hukum Progresif", Thafa Media, Yogyakarta, 2014

HS, Salim, Teknik Pembuatan Akta Pejabat Pembuat Akta Tanah, Raja Grafindo Persada, Jakarta, 2016

Ismaya, Samun, Hukum Administrasi Pertanahan, Graha Ilmu, Yogyakarta, 2013

\section{Jurnal}

Dhea Tri Febriana \& Ahars Sulaiman, "Tanggung Jawab Pejabat Pembuat Akta Tanah (PPAT) Dalam Pembuatan Akta Jual Beli Tanah Berdasarkan Peraturan Pemerintah Republik Indonesia Nomor 24 Tahun 2016 Tentang PPAT", Jurnal Petita, Vol. 1, No. 1, Juni 2019

Rio Utomo Hably \& Gunawan Djajaputra, "Kewenangan Notaris Dalam Hal Membuat Akta Partij (Contoh Kasus Putusan Mahkamah Agung Nomor: 1003 K/PID/2015)", Jurnal Hukum Adigama, Volume 2 Nomor 2, Desember 2019

\section{Peraturan Perundang-Undangan}

Undang-Undang Nomor 5 Tahun 1960 tentang Peraturan Dasar Pokok-Pokok Agraria Peraturan Pemerintah Nomor 24 tahun 1997 tentang Pendaftaran Tanah

Peraturan Pemerintah Nomor 37 Tahun 1998 yang diubah menjadi Peraturan Pemerintah Nomor 24 Tahun 2016 tentang Peraturan Jabatan Pembuat Pejabat Akta Tanah

\section{Data Elektronik}

https://www.hukumonline.com/klinik/detail/ulasan/cl1996/perbedaan-akta-yangdibuat-oleh-notaris-dengan-akta-yang-dibuat-di-hadapan-notaris/, diakses pada $13 / 10 / 2021$ 